\title{
Coenonia anatina gen. nov., sp. nov., a novel bacterium associated with respiratory disease in ducks and geese
}

\author{
P. Vandamme, ${ }^{1}$ M. Vancanneyt, ${ }^{2}$ P. Segers, ${ }^{1}$ M. Ryll, ${ }^{3}$ B. Köhler, ${ }^{4}$ \\ W. Ludwig ${ }^{5}$ and K.-H. Hinz ${ }^{3}$
}

Author for correspondence: P. Vandamme. Tel: +329264 5113. Fax: +3292645092. e-mail: Peter.Vandamme@rug.ac.be

\footnotetext{
1,2 Laboratory of Microbiology 1 and BCCM/LMG Culture Collection ${ }^{2}$, University of Ghent, Ledeganckstraat 35, B-9000 Gent, Belgium

3 Clinic for Poultry, School of Veterinary Medicine, Hannover, Germany

${ }^{4}$ State Veterinary Laboratory, Potsdam, Germany

5 Lehrstuhl für Mikrobiologie, Technische Universität München, Munich, Germany
}

\begin{abstract}
Taxon 1502 was originally described as a Riemerella anatipestifer-like bacterium causing exudative septicaemia in ducks and geese. In the present study, an integrated genotypic and phenotypic approach was used to elucidate the phylogenetic affiliation and taxonomic relationships of 12 strains of taxon 1502. Whole-cell protein and fatty acid analyses and an extensive biochemical examination by using conventional tests and several API microtest systems indicated that all isolates formed a homogeneous taxon, which was confirmed by DNA-DNA hybridizations. 16S rDNA sequence analysis of a representative strain (LMG 14382') indicated that this taxon belongs to the Cytophaga-Flavobacterium-Bacteroides phylum and revealed a moderate but distinct relationship to species of the genus Capnocytophaga (overall 165 rDNA sequence identities were 88.8-90.2\%). Taxon 1502 is concluded to represent a single species that should be allocated to a novel genus, and the name Coenonia anatina gen. nov., sp. nov. is proposed. The DNA G+C content of representative strains was $35-36$ mol\% and the type strain is LMG $14382^{\top}$.
\end{abstract}

Keywords: Coenonia anatina gen. nov., sp. nov., Capnocytophaga, taxon 1502, poultry

\section{INTRODUCTION}

Riemerella anatipestifer is a globally distributed agent of septicaemic disease in domestic and wild ducks and is of major economic importance (Brogden, 1989). In a recent study, Hinz et al. (1998) described various phenotypic characteristics of about $200 R$. anatipestifer and $R$. anatipestifer-like bacteria isolated mainly in Germany from various species of birds and swine. Sixty-four of these isolates, 59 of which were obtained from Pekin ducks, two from muscovy ducks and three from geese, differed considerably from all other strains examined (Hinz et al., 1998) and were referred to as $R$. anatipestifer-like bacteria of the taxon 1502 [1502 being the number of a representative strain $(=\mathrm{LMG}$ $\left.\left.14382^{\mathrm{T}}\right)\right]$.

In the present study, 12 randomly selected strains of taxon 1502 were used to elucidate the phylogenetic

The EMBL accession number for the 165 rDNA sequence of strain LMG $14382^{\top}$ reported in this paper is $Y 17612$. affiliation and taxonomic relationships of this taxon by means of an integrated genotypic and phenotypic approach. In the course of the study, members of the genus Capnocytophaga were shown to be the closest relatives of taxon 1502 strains. Therefore, representative strains of the various Capnocytophaga species characterized in a previous polyphasic taxonomic study (Vandamme et al., 1996) and of $R$. anatipestifer were included as references throughout the study.

\section{METHODS}

Bacterial strains and growth conditions. Unless specified otherwise, strains were grown on Trypticase Soy agar (BBL) and incubated at $36-37^{\circ} \mathrm{C}$ in a microaerobic atmosphere containing approximately $5 \% \mathrm{O}_{2}, 3 \cdot 5 \% \mathrm{CO}_{2}, 7 \cdot 5 \% \mathrm{H}_{2}$ and $84 \% \mathrm{~N}_{2}$. The strains and their sources are listed in Table 1. Bacteriological purity was checked by plating and examining living and Gram-stained cells.

Whole-cell protein analysis. Strains were grown for $2 \mathrm{~d}$. Preparation of cellular protein extracts, PAGE, densitometric analysis, normalization and interpolation of the protein profiles and numerical analysis were performed as 
Table 1. List of strains studied

\begin{tabular}{|c|c|c|c|}
\hline Strain & Other strain no.* & Received from & Source \\
\hline Coenonia anatina $\mathrm{LMG} 14382^{\mathrm{T}}$ & $1502-91^{\mathrm{T}}$ & (Own isolate) & Pekin duck (Germany, 1991) \\
\hline Coenonia anatina $\mathrm{LMG} 14383$ & $727-82$ & (Own isolate) & Pekin duck (Germany, 1982) \\
\hline Coenonia anatina LMG 14384 & $726-82$ & (Own isolate) & Muscovy duck (Germany, 1982) \\
\hline Coenonia anatina LMG 17807 & $481-85$ & (Own isolate) & Goose (Germany, 1985) \\
\hline Coenonia anatina LMG 17808 & $599-78$ & (Own isolate) & Muscovy duck (Germany, 1978) \\
\hline Coenonia anatina LMG 17809 & $461-84$ & (Own isolate) & Goose (Germany, 1984) \\
\hline Coenonia anatina LMG 17810 & G1219-92 & (Own isolate) & Pekin duck (Germany, 1992) \\
\hline Coenonia anatina LMG 17811 & G700-94 & (Own isolate) & Pekin duck (Germany, 1994) \\
\hline Coenonia anatina LMG 17812 & G1382-93 & (Own isolate) & Pekin duck (Germany, 1993) \\
\hline Coenonia anatina LMG 17813 & G31-94 & (Own isolate) & Pekin duck (Germany, 1994) \\
\hline Coenonia anatina LMG 17814 & G356-92 & (Own isolate) & Pekin duck (Germany, 1992) \\
\hline Coenonia anatina LMG 17815 & G157-93 & (Own isolate) & Pekin duck (Germany, 1993) \\
\hline Capnocytophaga canimorsus LMG 11510 & CCUG 12569 & CCUG & Human, blood (USA, 1965) \\
\hline Capnocytophaga cynodegmi LMG $11513^{\mathrm{T}}$ & CCUG $24742^{\mathrm{T}}$ & CCUG & Dog, mouth (USA, 1979) \\
\hline Capnocytophaga gingivalis LMG $11514^{\mathrm{T}}$ & CCUG $9715^{\mathrm{T}}$ & CCUG & Periodontitis (USA, 1978) \\
\hline Capnocytophaga granulosa LMG $16022^{\mathrm{T}}$ & $\mathrm{JCM} 8566^{\mathrm{T}}$ & JCM & Supragingival dental plaque (Japan) \\
\hline Capnocytophaga haemolytica LMG $16021^{\mathrm{T}}$ & $\mathrm{JCM} 8565^{\mathrm{T}}$ & JCM & Supragingival dental plaque (Japan) \\
\hline Capnocytophaga ochracea LMG 11516 & CCUG 9972 & CCUG & Bülow drain secretion (Sweden, 1980) \\
\hline Capnocytophaga sputigena LMG $11518^{\mathrm{T}}$ & CCUG $9714^{\mathrm{T}}$ & CCUG & Periodontitis (USA, 1978) \\
\hline Ornithobacterium rhinotracheale LMG $9086^{\mathrm{T}}$ & CCUG $23171^{\mathrm{T}}$ & CCUG & Turkey, respiratory tract (UK) \\
\hline Riemerella anatipestifer LMG $11054^{\mathrm{T}}$ & CCUG $21370^{\mathrm{T}}$ & CCUG & Duck, blood (USA) \\
\hline
\end{tabular}

*CCUG, Culture Collection University of Göteborg, Department of Clinical Bacteriology, Göteborg, Sweden; JCM, Japan Collection of Microorganisms, Institute of Physical and Chemical Research, Saitama, Japan; LMG, BCCM/LMG Culture Collection, Laboratorium voor Microbiologie Gent, Universiteit Gent, Belgium.

described by Pot et al. (1994) using the GELCOMPAR 4.0 software package (Applied Maths). The profiles were recorded and stored on a PC. The similarity between all pairs of traces was expressed by the Pearson product moment correlation coefficient converted, for convenience, to a percentage value.

Fatty acid methyl ester analysis. Strains were grown for $48 \mathrm{~h}$ and then a loopful of well-grown cells was harvested. Preparation, separation, identification and numerical comparison of the fatty acid methyl esters was performed using the Microbial Identification System (Microbial ID) as described before (Vandamme et al., 1992).

Preparation of high-molecular-mass DNA. High-molecularmass native DNA was prepared as described before (Vandamme et al., 1992).

DNA base compositions. All DNA $\mathrm{G}+\mathrm{C}$ contents were determined by thermal denaturation and calculated by using the equation of Marmur \& Doty (1962), as modified by De Ley (1970).

DNA-DNA hybridization experiments. The degree of DNADNA binding, expressed as a percentage, was determined spectrophotometrically by the initial renaturation rate method of De Ley et al. (1970). Each value is the mean of at least two hybridization experiments. Values of $30 \%$ DNA binding or less do not represent significant DNA homology. The total DNA concentration was about $52 \mu \mathrm{g} \mathrm{ml}^{-1}$ and the optimal renaturation temperature in $1 \times \mathrm{SSC}(0 \cdot 15 \mathrm{M} \mathrm{NaCl}$, $0 \cdot 015 \mathrm{M}$ sodium citrate, $\mathrm{pH} 7$ ) was $60 \cdot 3{ }^{\circ} \mathrm{C}$.

$16 S$ rDNA sequencing. In vitro amplification and direct sequencing of $16 \mathrm{~S}$ rRNA-encoding DNA fragments was done as described previously (Springer et al., 1992). The new 16S rRNA sequence was fitted into an alignment of about 12000 homologous, full and partial primary structures available in public databases (Ludwig, 1995) using the respective automated tools of the ARB software package (Ludwig \& Strunk, 1996). Distance matrix, maximumparsimony and maximum-likelihood methods were applied, as implemented in the ARB software package. Different data sets, varying with respect to the outgroup reference organisms included (sequences) as well as alignment positions, were analysed (Ludwig et al., 1998).

Phenotypic tests. Classical biochemical tests were performed as described before (Vandamme et al., 1998). The basal medium used was Columbia agar (Oxoid) supplemented with $7 \%$ defibrinated sheep blood; microaerobic and anaerobic growth conditions were generated by means of the Oxoid Campylobacter gas-generation kit and Anaerocult- $\mathrm{A}$ system (Merck), respectively. The following characters were examined: growth on MacConkey agar, Simmons citrate agar and litmus lactose agar; presence of phenylalanine deaminase, oxidase, catalase, urease, ornithine and lysine decarboxylase, arginine dihydrolase, hyaluronidase and chondroitin sulfatase activity; indole production; hydrolysis of gelatin and aesculin; nitrate reduction; utilization of malonate as carbon source; and methyl red and VogesProskauer reaction (production of acetylmethylcarbinol).

Acid production from carbohydrates was tested by using the conventional test system and buffered single-substrate procedure as described before (Vandamme et al., 1998). The API 20NE, API ZYM and API ID 32 E microtest systems 
were used according to the recommendations of the manufacturer (bioMérieux).

\section{RESULTS}

\section{PAGE of whole-cell proteins}

Duplicate protein extracts of several strains were prepared to check the reproducibility of the growth conditions and the preparation of the extracts. The correlation between duplicate protein patterns was $>94 \%$. All 12 taxon 1502 strains examined had virtually identical whole-cell protein patterns, which clustered above a correlation of $91 \%$ (Fig. 1).

\section{Fatty acid methyl ester composition}

The mean whole-cell fatty acid composition of the 12 strains of taxon 1502 is given in Table 2. It typically comprised 13:0 iso (about 34\%), 14:0 (about 3\%), $15: 0$ iso (about $41 \%$ ), 15:0 anteiso (about $3 \%$ ), 15:0 iso 3-OH (about 6.5\%), 16:0 3-OH (about 4\%) and $17: 0$ iso $3-\mathrm{OH}$ (about $6 \cdot 5 \%$ ).

\section{DNA base composition}

The DNA G + C content of strains LMG $14382^{\mathrm{T}}$, LMG 17808 and LMG 17809 was 35,35 and $35.5 \mathrm{~mol} \%$, respectively.

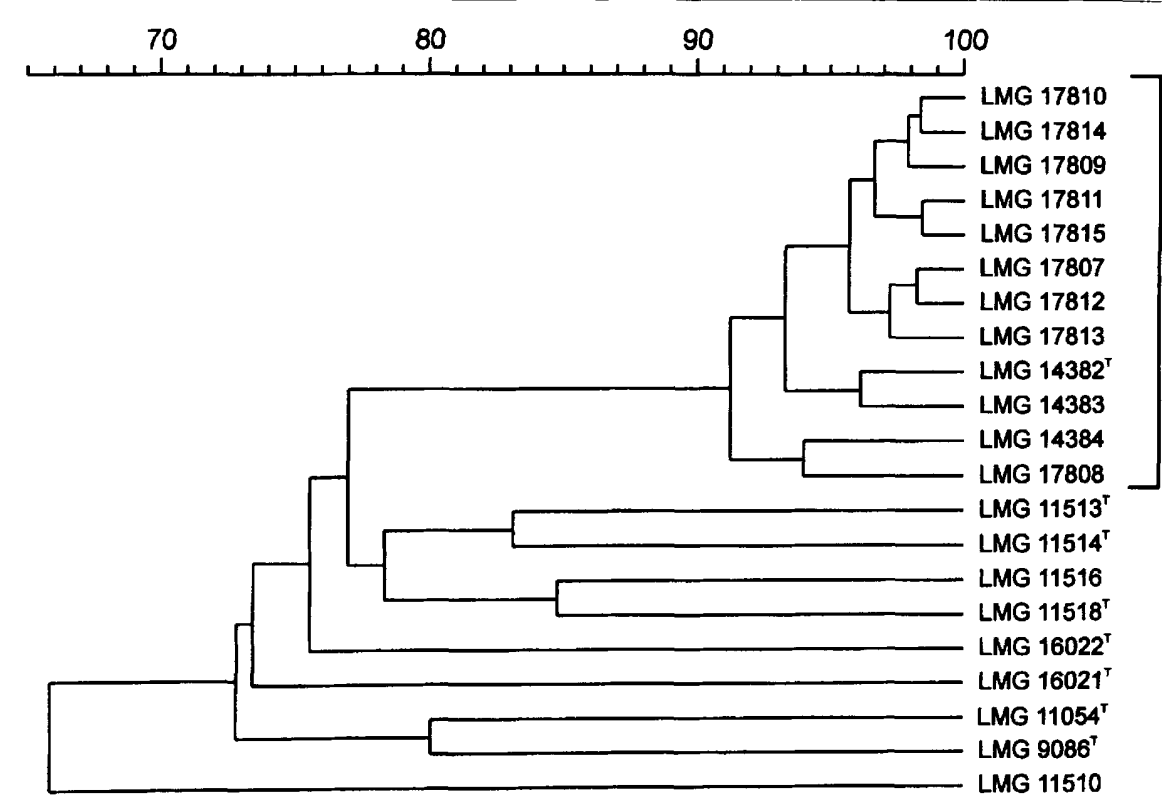

Coenonia anatina

Capnocytophaga cynodogmi Capnocytophaga gingivalis Capnocytophaga ochracea Capnocytophaga sputigena Capnocytophaga granulosa Capnocytophaga haemolytica Riemerella anatipestifer Omithobacterium minotracheale Capnocytophaga canimorsus

Fig. 1. Dendrogram derived from the unweighted pair group mean linkage of correlation coefficients between wholeorganism protein patterns of all strains examined.

Table 2. Fatty acid composition of the strains studied

The number of strains of each taxon examined is indicated. Those fatty acids for which the mean amount for all taxa was less than $1 \%$ are not shown. Therefore, the percentages for each group do not total 100 . Mean percentages \pm standard deviations are given. TR, Trace amount $(<1 \%)$; ND, not detected. ECL, equivalent chain-length value. Data for Capnocytophaga species were from Vandamme et al. (1996).

\begin{tabular}{|c|c|c|c|c|c|c|c|c|c|c|c|}
\hline Taxon $(n)$ & $13: 0$ iso & ECL 13.566 & $14: 0$ & $15: 0$ iso & $15: 0$ anteiso & $15: 0$ & $16: 0$ & $\begin{array}{c}15: 0 \text { iso } \\
3-O H\end{array}$ & ECL $16 \cdot 580$ & $16: 03-\mathrm{OH}$ & $\begin{array}{c}17: 0 \text { iso } \\
3-\mathrm{OH}\end{array}$ \\
\hline Coenonia anatina $(12)$ & $33 \cdot 9 \pm 4 \cdot 6$ & TR & $2 \cdot 8 \pm 2 \cdot 4$ & $40 \cdot 8 \pm 4 \cdot 7$ & $3 \cdot 2 \pm 0 \cdot 7$ & $\mathrm{ND}$ & TR & $6 \cdot 4 \pm 1 \cdot 3$ & ND & $4 \cdot 1 \pm 0 \cdot 9$ & $6 \cdot 3 \pm 2 \cdot 3$ \\
\hline Riemerella anatipestifer $(16)^{*}$ & $14.9 \pm 3.6$ & $1 \cdot 5 \pm 0 \cdot 6$ & ND & $52 \cdot 8 \pm 4 \cdot 9$ & $5 \cdot 8 \pm 1 \cdot 8$ & ND & TR & $8 \cdot 0 \pm 2 \cdot 8$ & TR & ND & $13 \cdot 1 \pm 3 \cdot 5$ \\
\hline Ornithobacterium rhinotracheale $(21) \dagger$ & TR & $4 \cdot 2 \pm 1 \cdot 5$ & TR & $57 \cdot 4 \pm 6 \cdot 1$ & TR & ND & $2 \cdot 9 \pm 1 \cdot 3$ & $8 \cdot 1 \pm 1 \cdot 9$ & $1 \cdot 1 \pm 0 \cdot 5$ & $2 \cdot 8 \pm 1 \cdot 8$ & $20 \cdot 2 \pm 5 \cdot 0$ \\
\hline Capnocytophaga canimorsus (5) & $1 \cdot 3 \pm 0.5$ & $2 \cdot 2 \pm 0 \cdot 8$ & $1 \cdot 7 \pm 0 \cdot 1$ & $66 \cdot 7 \pm 1 \cdot 7$ & $1.4 \pm 0.5$ & ND & $2 \cdot 3 \pm 0 \cdot 5$ & $6.6 \pm 1.6$ & TR & $4 \cdot 3 \pm 0 \cdot 7$ & $11 \cdot 5 \pm 0 \cdot 4$ \\
\hline Capnocytophaga cynodegmi (4) & $1.0 \pm 0.4$ & $1.9 \pm 0.7$ & $2 \cdot 2 \pm 0 \cdot 7$ & $66 \cdot 5 \pm 4 \cdot 7$ & $1.3 \pm 0.5$ & ND & $2 \cdot 8 \pm 0 \cdot 4$ & $3 \cdot 9 \pm 0 \cdot 6$ & $1 \cdot 0 \pm 0 \cdot 2$ & $4 \cdot 6 \pm 2 \cdot 5$ & $12 \cdot 9 \pm 3 \cdot 6$ \\
\hline Capnocytophaga gingivalis (3) & $3.9 \pm 0.7$ & $1 \cdot 7 \pm 0 \cdot 3$ & $1 \cdot 0 \pm 0.1$ & $63 \cdot 5 \pm 4 \cdot 9$ & $1.8 \pm 0.2$ & $1 \cdot 6 \pm 0 \cdot 9$ & $1.9 \pm 1.1$ & $2 \cdot 6 \pm 1 \cdot 1$ & $1 \cdot 2 \pm 0 \cdot 3$ & $5 \cdot 7 \pm 1 \cdot 5$ & $14 \cdot 0 \pm 2 \cdot 2$ \\
\hline Capnocytophaga ochracea (6) & $2 \cdot 1 \pm 0 \cdot 5$ & $1 \cdot 3 \pm 0 \cdot 4$ & $1.5 \pm 0.8$ & $63 \cdot 5 \pm 9 \cdot 3$ & $1.6 \pm 1.0$ & TR & $3 \cdot 6 \pm 2 \cdot 3$ & $1 \cdot 2 \pm 0 \cdot 4$ & TR & $8 \cdot 1 \pm 6 \cdot 6$ & $13 \cdot 8 \pm 2 \cdot 8$ \\
\hline Capnocytophaga sputigena (5) & $2 \cdot 9 \pm 1 \cdot 0$ & $1 \cdot 2 \pm 0.9$ & $2 \cdot 2 \pm 1 \cdot 0$ & $68 \cdot 0 \pm 2 \cdot 1$ & $1.9 \pm 0.3$ & TR & $4 \cdot 2 \pm 1 \cdot 5$ & $1 \cdot 2 \pm 0.4$ & $\mathrm{TR}$ & $5 \cdot 9 \pm 1 \cdot 2$ & $9 \cdot 7 \pm 2 \cdot 9$ \\
\hline Capnocytophaga granulosa (5) & $2 \cdot 1 \pm 1 \cdot 0$ & TR & $1.9 \pm 1.2$ & $75 \cdot 5 \pm 6 \cdot 8$ & $1 \cdot 3 \pm 0 \cdot 3$ & TR & $4 \cdot 2 \pm 4 \cdot 0$ & $1.6 \pm 0.5$ & $\mathrm{TR}$ & $5 \cdot 0 \pm 2 \cdot 7$ & $6.5 \pm 1 \cdot 7$ \\
\hline Capnocytophaga haemolytica (1) & TR & TR & $2 \cdot 2$ & $60 \cdot 7$ & 1.8 & TR & $9 \cdot 8$ & TR & TR & 8.4 & $9 \cdot \overline{4}$ \\
\hline
\end{tabular}

* Data from Segers et al. (1993).

$\dagger$ Data from Vandamme et al. (1994). O. rhinotracheale strains also contain 1.5 $\pm 1.0 \% 17: 0$ iso. 


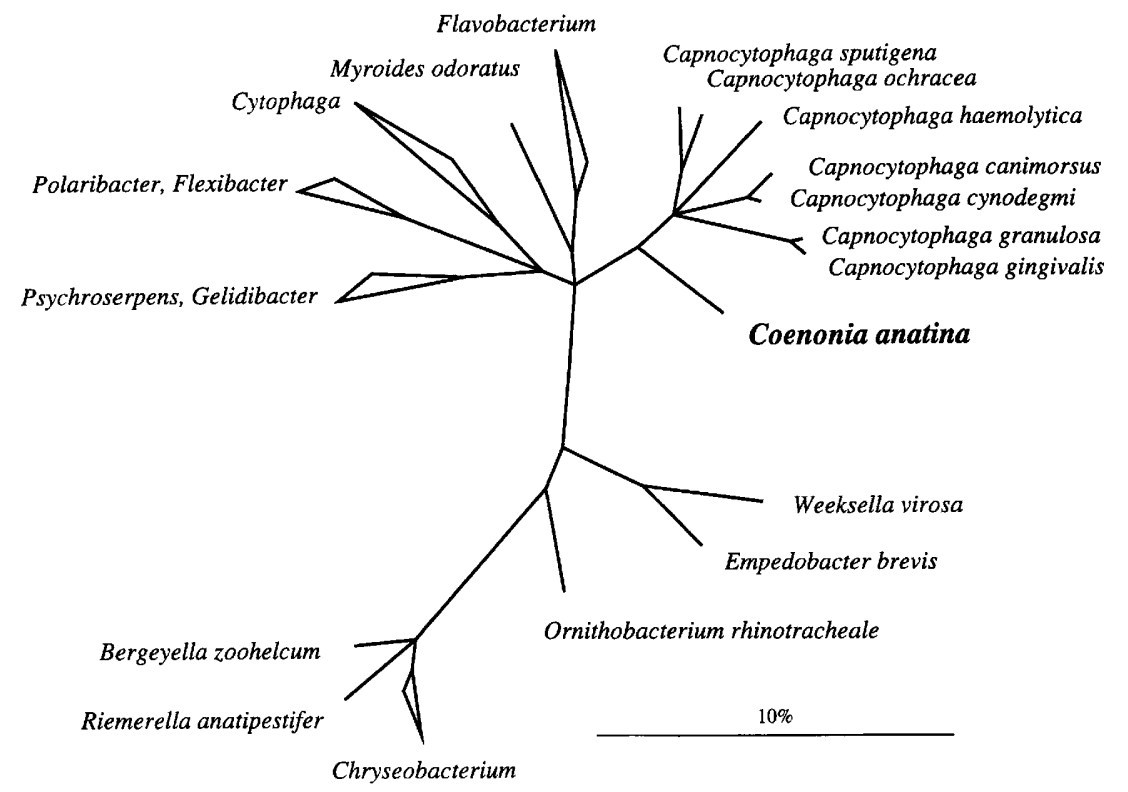

Fig. 2. $16 \mathrm{~S}$ rRNA-based tree reflecting the phylogenetic relationships of strain LMG $14382^{\top}$ and a selection of related species and groups. A maximum-likelihood tree was reconstructed from a data set of 160 almost-complete 16S rRNA sequences from representatives of the Cytophaga-Flavobacterium-Bacteroides phylum. Only alignment positions which share identical nucleotides in at least $50 \%$ of the entire data-set of all available 16S rRNA sequences from the phylum were included for calculations. The tree topology was corrected according the results of distance-matrix and maximumparsimony analyses of all available $16 \mathrm{~S}$ rRNA sequences from the phylum or the full data-set of 12000 sequence entries, respectively. Multifurcations indicate that a relative branching order could not be determined unambiguously or a common branching order was not supported when applying different treeing methods on varying data sets. The bar indicates $10 \%$ estimated sequence divergence. The following strains were used as references (accession numbers are given in parentheses): Psychroserpens burtonensis ACAM181 (U62912), Gelidibacter algens A296 (U62916), Cytophaga marinoflava ATCC $19326^{\top}$ (M58770), Flavobacterium gondwanense ATCC $51278^{\top}$ (M92278), Flavobacterium salegens DSM $5424^{\top}$ (M92279), Cytophaga latercula ATCC $23177^{\top}$ (M58769), Polaribacter filamentus 215 (U73726), Flexibacter maritimus (strain is not specified) (M58780), Cytophaga uliginosa ATCC 14397 ${ }^{\top}$ (M28238) and NCIMB 1863' (M62799), Cytophaga Iytica ATCC $23178^{\top}$ (M28058 and M62796), Capnocytophaga ochracea ATCC $33596^{\top}$ (X67610), Capnocytophaga sputigena ATCC $33612^{\top}$ (X67609), Capnocytophaga haemolytica LMG $16021^{\top}$ (U41349), Capnocytophaga canimorsus ATCC $35979^{\top}$ (L14637), Capnocytophaga cynodegmi ATCC 49044 (L14638), Capnocytophaga granulosa LMG 12119 (U41348), Capnocytophaga gingivalis LMG 12118 (U41346), Flavobacterium columnare ATCC 43622 (M58781), Flavobacterium johnsoniae ATCC $17061^{\top}$ (M59051), Flavobacterium flevense ATCC $27944^{\top}$ (M58767), Flavobacterium aquatile ATCC 11947 ${ }^{\top}$ (M28236 and M62797), Myroides odoratus NCTC 11036 ${ }^{\top}$ (M58777), Chryseobacterium indologenes ATCC 29897 ${ }^{\top}$ (M58773), Chryseobacterium gleum ATCC 35910 ${ }^{\top}$ (M58772), Bergeyella zoohelcum ATCC 43767 ${ }^{\top}$ (M93153), Chryseobacterium balustinum ATCC 33487 ${ }^{\top}$ (M58771), Chryseobacterium indoltheticum ATCC $27950^{\top}$ (M58774), Riemerella anatipestifer ATCC $11845^{\top}$ (U10877), Empedobacter brevis ATCC 14234 (M59052), Weeksella virosa ATCC 43766 ${ }^{\top}$ (M93152) and Ornithobacterium rhinotracheale LMG $9086^{\top}$ (L19156).

\section{DNA-DNA hybridization results}

The DNA-DNA binding level between LMG $14382^{\mathrm{T}}$ and LMG 17808 was $55 \%$ and the DNA-DNA binding level between LMG $14382^{\mathrm{T}}$ and LMG 17809 was $85 \%$.

\section{Phylogenetic analysis of the 16S rDNA sequence}

16S rRNA-encoding DNA from strain LMG $14382^{\mathrm{T}}$ was amplified in vitro and sequenced directly. A comparative database analysis revealed a moderate but distinct relationship to the species of the genus Capnocytophaga (Fig. 2). The overall 16S rRNA sequence identities were $88 \cdot 8-90 \cdot 2 \%$. These species represent a monophyletic sub-group of the bacterial phylum Cytophaga-Flavobacterium-Bacteroides, containing strain LMG $14382^{\mathrm{T}}$ as its deepest branch.
Neighbour groups comprise species of the genera Ornithobacterium, Riemerella, Gelidibacter, Myroides, Polaribacter and Psychroserpens as well as members of the phylogenetically heterogeneous genus Flexibacter and the emended genera Flavobacterium and Cytophaga and various taxa previously classified as flavobacteria or cytophagas (Vandamme et al., 1994; Bernardet et al., 1996; Vancanneyt et al., 1996; Nakagawa \& Yamasoto, 1996). The corresponding overall sequence identities for strain LMG $14382^{\mathrm{T}}$ and the representatives of these groups were $88.6 \%$ and lower.

\section{Phenotypic tests}

Phenotypic tests were performed on all taxon 1502 strains and the reference Capnocytophaga strains included in Table 1. When tests were performed in 
Table 3. Differential phenotypic characteristics of all strains examined

Symbols used: + , characteristic present; - , characteristic absent; $(+)$, characteristic weakly present or reaction delayed; $v$, strain-dependent reaction. In the case of strain-dependent reactions, the number of strains giving a positive reactions is given in parentheses. Capn., Capnocytophaga.

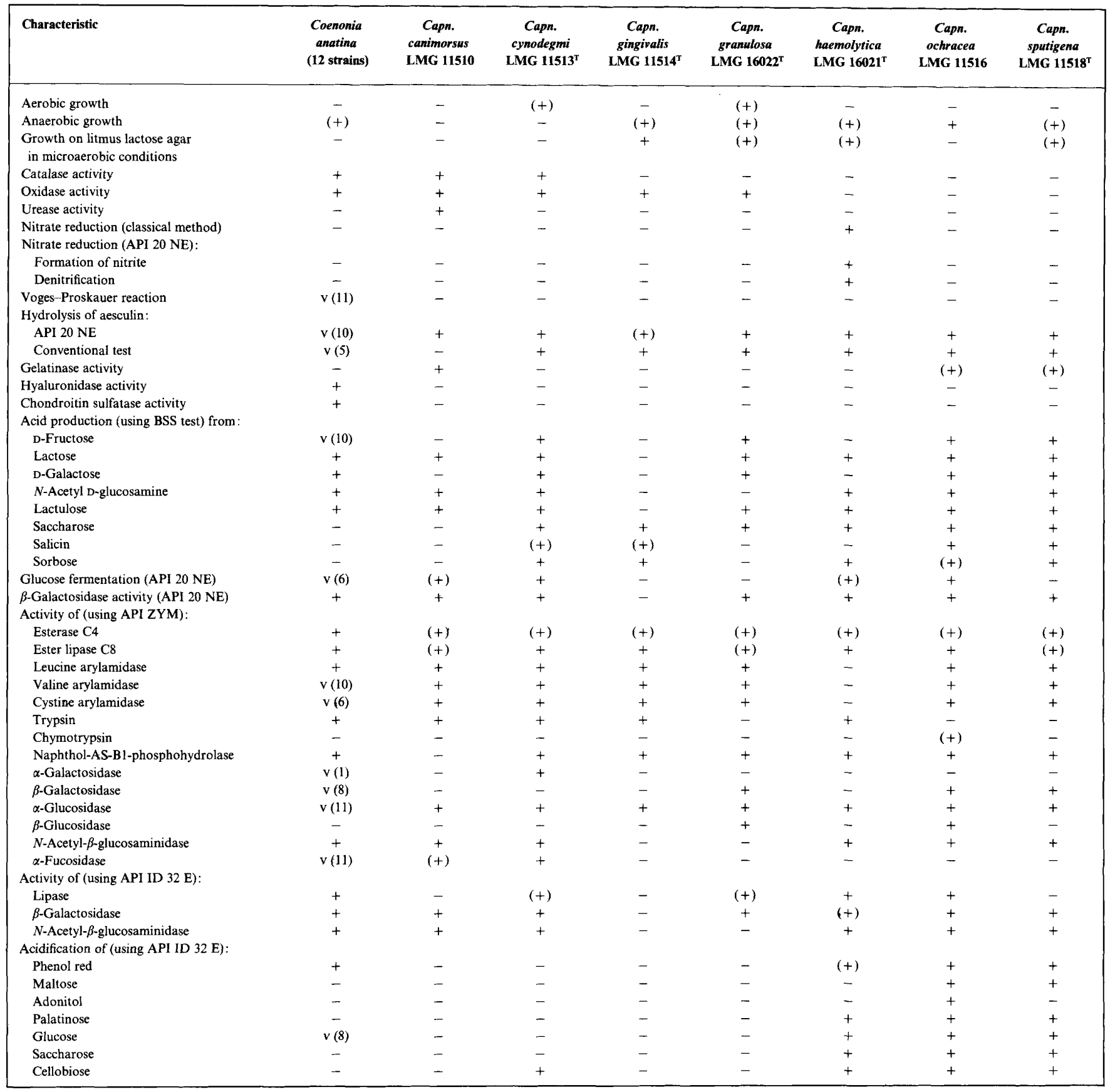

multiple API microtest systems or in a conventional way and by means of API microtest systems, identical results were usually obtained. Discrepancies were however observed for aesculin hydrolysis [present in 17 strains when examined by using API 20NE; absent in eight strains when performed by using the classical method (aesculin broth; Merck)], gelatinase activity [absent in all strains when examined by using API $20 \mathrm{NE}$; present or weakly present in three strains when examined by using the classical method (gelatin agar: standard I nutrient agar, Merck catalogue no. 7881, supplemented with $0.4 \%$ gelatin)], acidification of maltose, glucose (always present when using the BSS test; variable reactions when using the API ID $32 \mathrm{E}$ microtest system) and saccharose (variable reactions when using the BSS test, but less-positive results when using the API ID 32 E microtest system) and activity of $\alpha$-glucosidase, $\beta$-glucosidase, $\alpha$-galactosidase (always 
present when using the API ID 32 E microtest system, variable reactions when using the API ZYM microtest system), $N$-acetyl $\beta$-glucosaminidase and $\beta$-galactosidase (variable reactions when using the API ID $32 \mathrm{E}$ microtest system, but less-positive results when using the API ZYM microtest system). Clearly, the API ZYM gallery seems to have a lower detection sensitivity than the other microtest systems used.

The following characters were present in all of the strains examined: growth on blood agar in microaerobic conditions; acid production from D-glucose, maltose, D-mannose and dextrin in BSS medium; activity of alkaline and acid phosphatase as determined by using the API ZYM microtest system; aesculin hydrolysis as determined by using the API $20 \mathrm{NE}$ microtest system (one strain, Capnocytophaga gingivalis $\mathrm{LMG} 11514^{\mathrm{T}}$, gave a weak reaction); and activity of $\alpha$-glucosidase, $\beta$-glucosidase (two strains of taxon 1502 gave negative reactions; one strain, Capnocytophaga gingivalis $\mathrm{LMG} 11514^{\mathrm{T}}$, gave a weak reaction), $\alpha$-galactosidase, $\alpha$-maltosidase and L-aspartic acid arylamidase as determined by using the API ID 32 E microtest system.

The following characters were absent in all of the strains examined: growth on MacConkey agar in microaerobic conditions; utilization of citrate; indole production; growth on Simmons citrate agar; methyl red reaction; activity of arginine dihydrolase, ornithine and lysine decarboxylase; alkali from malonate and phenylalanine deaminase activity (as determined by using classical phenotypic tests); acid production from trehalose, adonitol, L-arabinose, dulcitol, myo-inositol, D-mannitol, D-sorbitol and D-xylose in BSS medium; indole production, activity of arginine dihydrolase and urease, liquefaction of gelatin and assimilation of D-glucose, L-arabinose, D-mannose, Dmannitol, $N$-acetyl-glucosamine, maltose, D-gluconate, caprate, adipate, L-malate, citrate and phenyl acetate as determined by using the API 20NE microtest system; activity of lipase $\mathrm{C} 14, \beta$-glucuronidase and $\alpha$ mannosidase as determined by using the API ZYM microtest system; and activity of arginine dihydrolase, ornithine and lysine decarboxylase, urease and $\beta$ glucuronidase, indole production and acidification of L-arabitol, galacturonate, 5-ketogluconate, mannitol, L-arabinose, D-arabitol, trehalose, rhamnose, inositol and sorbitol as determined by using the ID $32 \mathrm{E}$ microtest system.

All other tests results were variable amongst strains or amongst taxa and are presented in Table 3.

\section{DISCUSSION}

\section{Phylogenetic allocation of taxon 1502 bacteria}

In the present study, a collection of 12 strains of taxon 1502 bacteria (Hinz et al., 1998) was examined by a polyphasic taxonomic approach. Although initially identified as $R$. anatipestifer-like bacteria, these strains were reported to differ in not less than 17 biochemical tests from typical $R$. anatipestifer strains, which indicated strongly that they represented a distinct taxon. Whole-cell protein (Fig. 1) and fatty acid analysis (Table 2) of 12 strains of taxon 1502 indicated that these isolates formed a single species, which was confirmed by DNA-DNA binding studies between strain LMG $14382^{\mathrm{T}}$ and two additional isolates, selected at random (values of 55 and $85 \%$ were measured).

Comparative $16 \mathrm{~S}$ rDNA sequence analyses applying alternative treeing methods upon various data sets clearly supported the phylogenetic position of strain LMG $14382^{\mathrm{T}}$ as a member of the Cytophaga -Flavobacterium-Bacteroides phylum of the Bacteria. This strain is affiliated to the species of the genus Capnocytophaga but significantly separated from the latter and other microaerophilic and capnophilic organisms such as Ornithobacterium and Riemerella species (Fig. 2). Whereas no stable relative branching order could be found for the phylogenetic sub-groups of Capnocytophaga, the separate status of strain LMG $14382^{\mathrm{T}}$ was evident in all treeing analyses. The tree topologies, in combination with the rather low overall 16S rRNA sequence identities of strain LMG $14382^{\mathrm{T}}$ and the other representatives of the phylum, support the description of the isolate as the representative of a new genus and species. The name Coenonia anatina gen. nov., sp. nov. is proposed below.

\section{Identification of Coenonia anatina}

Phenotypically, Coenonia anatina (taxon 1502) was reported to be more similar to Ornithobacterium rhinotracheale [another member of the Cytophaga -Flavobacterium-Bacteroides phylum that is frequently isolated from poultry specimens (Vandamme et al., 1994)] than to R. anatipestifer (Hinz et al., 1998). Hinz et al. (1998) described a variety of differential biochemical tests to distinguish between these three taxa. The most important characters that allow the differentiation of Coenonia anatina from $R$. anatipestifer are the absence of arginine dihydrolase and gelatinase activity, the presence of hyaluronidase and chondroitin sulfatase activity, aesculin hydrolysis and the presence of $\beta$-glucosaminidase activity (as determined by using the API ZYM microtest system). Coenonia anatina strains are readily differentiated from $O$. rhinotracheale strains by the presence of catalase activity and the absence of urease and arginine dihydrolase activity. Features that allow the differentiation of Coenonia anatina from Capnocytophaga species (its closest phylogenetic neighbours) are a positive Voges-Proskauer reaction, the presence of hyaluronidase and chondroitin sulfatase activity and absence of $\alpha$-glucosidase activity (as determined using the API ZYM microtest system). A variety of additional tests differentiating Coenonia anatina from individual Capnocytophaga species is listed in Table 3.

In addition, whole-cell protein (Fig. 1) and fatty acid analysis (Table 2) allow ready differentiation of 
Coenonia anatina from species belonging to the genera Riemerella, Ornithobacterium and Capnocytophaga. The cellular fatty acid of Coenonia anatina strains is primarily composed of a variety of branched-chain fatty acids, which is typical for members of this phylogenetic lineage.

\section{Description of Coenonia gen. nov.}

Coenonia (coe.no'ni.a. Gr. n. coenonia community, association; N.L. fem. n. Coenonia refers to the association between these bacteria and a host).

Coenonia cells are Gram-negative, non-spore-forming, microaerophilic, non-motile, rod-shaped bacteria. The major fatty acid components of all strains examined are branched-chain fatty acids, including 13:0 iso, $15: 0$ iso, $15: 0$ anteiso, $15: 0$ iso $3-\mathrm{OH}, 16: 03-\mathrm{OH}$ and 17:0 iso $3-\mathrm{OH}$. The DNA $\mathrm{G}+\mathrm{C}$ content of representative strains was $35-36 \mathrm{~mol} \%$ and the type species is Coenonia anatina sp. nov.

\section{Description of Coenonia anatina sp. nov.}

Coenonia anatina (a.na.ti'na. L. adj. anatinus of a duck).

Cells are Gram-negative, non-spore-forming rods. Non-motile. In 16-h-old cultures on blood agar, the mean cell size is $0 \cdot 2-0.4 \mu \mathrm{m}$ in width and $1.25-2.5 \mu \mathrm{m}$ in length. Some cells are spherically swollen, spindleor lemon-shaped and arranged in short chains. Strains produce flat-convex, circular and non-pigmented to whitish colonies with entire edges and a smooth surface on blood agar. The strains do not require special growth factors and grow on conventional media. Growth is optimal at $37^{\circ} \mathrm{C}$ in a microaerobic and $\mathrm{CO}_{2}$ enriched atmosphere. Growth is weak in anaerobic conditions and absent in aerobic conditions. No growth on MacConkey agar or on Simmons citrate agar. Non-haemolytic. All strains produce catalase and oxidase activity. Hyaluronidase and chondroitin sulfatase activity is present. No urease, gelatinase, arginine dihydrolase, phenylalanine deaminase or ornithine or lysine decarboxylase activity. No reduction of nitrate. Hydrolysis of aesculin. Production of acetylmethylcarbinol but not indole. Methyl red reaction is negative. No utilization of citrate. No alkali from malonate. Acid production in BSS medium from D-glucose, D-fructose, maltose, D-mannose, lactose, Dgalactose, $N$-acetyl glucosamine, lactulose and dextrin but not from trehalose, adonitol, L-arabinose, dulcitol, myo-inositol, D-mannitol, D-sorbitol, saccharose, salicin, sorbose or D-xylose. Using the API ZYM microtest system, activities of alkaline and acid phosphatase, esterase C4, ester lipase C8, leucine, valine and cystine arylamidase, naphthol-AS-B1-phosphohydrolase, $\beta$ galactosidase, $\alpha$-glucosidase, $N$-acetyl- $\beta$-glucosaminidase, $\alpha$-fucosidase and trypsin are detected; activity of lipase $\mathrm{C} 14$, chymotrypsin, $\beta$-glucuronidase, $\alpha$-galactosidase, $\beta$-glucosidase and $\alpha$-mannosidase are not detected. Using the API ID $32 \mathrm{E}$ microtest system, acidification of glucose and activities of $\alpha$-glucosidase, $\beta$-glucosidase, $\alpha$-galactosidase, $\beta$-galactosidase, $\alpha$ maltosidase, lipase, $N$-acetyl- $\beta$-glucosaminidase and L-aspartic acid arylamidase are detected; activities of arginine dihydrolase, ornithine and lysine decarboxylase, urease and $\beta$-glucuronidase, indole production and acidification of L-arabitol, galacturonate, 5-ketogluconate, mannitol, L-arabinose, D-arabitol, trehalose, rhamnose, inositol, maltose, adonitol, palatinose, saccharose, cellobiose and sorbitol are not detected. The major fatty acid components of all strains examined are 13:0 iso (about 34\%), 14:0 (about 3\%), 15:0 iso (about $41 \%$ ), 15:0 anteiso (about 3\%), 15:0 iso 3-OH (about 6.5\%), 16:0 3-OH (about 4\%) and 17:0 iso 3-OH (about 6.5\%). Strains have been isolated as pure cultures under microaerobic conditions from samples of the respiratory tract (lungs, airsac fibrin, pericard) and brain of ducks and geese, always associated with signs similar to those of $R$. anatipestifer-associated exudative septicaemia. In the northern part of Germany, Coenonia anatina strains were recovered from over $30 \%$ of the cases of septicaemia-related losses in commercial duck flocks in the period 1994-1995. Vaccination with an inactivated whole culture of Coenonia anatina strains induced protection of ducklings against Coenonia anatinaassociated disease. These data suggest its pathogenic role. The DNA G $+\mathrm{C}$ content of representative strains varied between 35 and $36 \mathrm{~mol} \%$. All Coenonia anatina strains listed in Table 1 have been deposited in the BCCM/LMG bacteria collection (URL http://www. belspo.be/bccm/lmg.htm). The type strain is $\mathrm{LMG}$ $14382^{\mathrm{T}}$, which was isolated from a Pekin duck in Germany. Its DNA G $+\mathrm{C}$ content is $35 \mathrm{~mol} \%$.

\section{ACKNOWLEDGEMENTS}

P.V. is indebted to the Fund for Scientific ResearchFlanders (Belgium) for a position as a post-doctoral fellow. Our research was also supported by the Prime Minister's Services-Federal Office for Scientific, Technical and Cultural Affairs, Belgium. We thank R. Coopman, D. Dewettinck and $\mathrm{R}$. Leise for excellent technical assistance.

\section{REFERENCES}

Bernardet, J.-F., Segers, P., Vancanneyt, M., Berthe, F., Kersters, K. \& Vandamme, P. (1996). Cutting a Gordian knot: emended classification and description of the genus Flavobacterium, emended description of the family Flavobacteriaceae, and proposal of Flavobacterium hydatis nom. nov. (basonym, Cytophaga aquatilis Strohl and Tait 1978). Int J Syst Bacteriol 46, 128-148.

Brogden, K. A. (1989). Pasteurella anatipestifer infection. In Pasteurella and Pasteurellosis, pp. 115-129. Edited by C. Adlam \& J. M. Rutter. London: Academic Press.

De Ley, J. (1970). Re-examination of the association between melting point, buoyant density, and chemical base composition of deoxyribonucleic acid. $J$ Bacteriol 101, 738-754.

De Ley, J., Cattoir, H. \& Reynaerts, A. (1970). The quantitative measurement of DNA hybridization from renaturation rates. Eur J Biochem 12, 133-142. 
Hinz, K.-H., Ryll, M., Köhler, B. \& Glünder, G. (1998). Phenotypic characteristics of Riemerella anatipestifer and similar microorganisms from various hosts. Avian Pathol 27, 33-42.

Ludwig, W. (1995). Sequence databases. In Molecular Microbial Ecology Manual, 3.3.5, pp. 1-22. Edited by A. D. L. Akkermans, J. D. van Elsas \& F. J. de Bruijn. Dordrecht: Kluwer.

Ludwig , W. \& Strunk, O. (1996). ARB - a software environment for sequence data. http://www.mikro.biologie.tu-muenchen. $\mathrm{de} / \mathrm{pub} / \mathrm{ARB} /$ documentation/arb.ps

Ludwig, W., Strunk, O., Klugbauer, S., Klugbauer, N., Weizenegger, M., Neumaier, J., Bachleitner, M. \& Schleifer, K. H. (1998). Bacterial phylogeny based on comparative sequence analysis. Electrophoresis 19, 554-568.

Marmur, J. \& Doty, P. (1962). Determination of the base composition of deoxyribonucleic acid from its thermal denaturation temperature. $J$ Mol Biol 5, 109-118.

Nakagawa, Y. \& Yamasato, K. (1996). Emendation of the genus Cytophaga and transfer of Cytophaga agarovorans and Cytophaga salmonicolor to Marinilabilia gen. nov.: phylogenetic analysis of the Flavobacterium-Cytophaga complex. Int J Syst Bacteriol 46, 599-603.

Pot, B., Vandamme, P. \& Kersters, K. (1994). Analysis of electrophoretic whole-organism protein fingerprints. In Modern Microbial Methods. Chemical Methods in Prokaryotic Systematics, pp. 493-521. Edited by M. Goodfellow \& A. G. O'Donnell. Chichester: Wiley.

Segers, P., Mannheim, W., Vancanneyt, M., De Brandt, K., Hinz, K.-H., Kersters, K. \& Vandamme, P. (1993). Riemerella anatipestifer gen. nov., comb. nov., the causative agent of septicemia anserum exsudativa, and its phylogenetic affiliation within the Flavobacterium-Cytophaga rRNA homology group. Int J Syst Bacteriol 43, 768-776.

Springer, N., Ludwig, W., Drozanski, V., Amann, R. \& Schleifer, K. H. (1992). The phylogenetic status of Sarcobium lyticum, an obligate intracellular parasite of small amoebae. FEMS Microbiol Lett 96, 199-202.

Vancanneyt, M., Segers, P., Torck, U., Hoste, B., Bernardet, J.-F., Vandamme, P. \& Kersters, K. (1996). Reclassification of Flavobacterium odoratum (Stutzer 1929) strains to a new genus, Myroides, as Myroides odoratus comb. nov. and Myroides odoratimimus sp. nov. Int J Syst Bacteriol 46, 926-932.

Vandamme, P., Vancanneyt, M., Pot, B. \& 10 other authors (1992). Polyphasic taxonomic study of the emended genus Arcobacter with Arcobacter butzleri comb. nov. and Arcobacter skirrowii sp. nov., an aerotolerant bacterium isolated from veterinary specimens. Int $J$ Syst Bacteriol 42, 344-356.

Vandamme, P., Segers, P., Vancanneyt, M. \& 11 other authors (1994). Ornithobacterium rhinotracheale gen. nov., sp. nov., isolated from the avian respiratory tract. Int J Syst Bacteriol 44, 24-37.

Vandamme, P., Vancanneyt, M., Van Belkum, A., Segers, P., Quint, W. G. V., Kersters, K., Paster, B. J. \& Dewhirst, F. E. (1996). Polyphasic analysis of strains of the genus Capnocytophaga and Centers for Disease Control group DF-3. Int J Syst Bacteriol 46, 782-791.

Vandamme, P., Segers, P., Ryll, M. \& 8 other authors (1998). Pelistega europaea gen. nov., sp. nov., a bacterium associated with respiratory disease in pigeons: taxonomic structure and phylogenetic allocation. Int J Syst Bacteriol 48, 431-440. 